Potential Sources for the Radiation Treatment of Food

W.E. Sande

R.A. Libby

August 1976

Prepared for the Energy Research and Development Administration under Contract E(45-1)-1830 
NOTICE

This report was prepared as an account of work sponsored by the United States Government. Neither the United States nor the Energy Research and Development Administration, nor any of their employees, nor any of their contractors, subcontractors, or their employees, makes any warranty, express or implied, or assumes any legal liability or responsibility for the accuracy, completeness or usefulness of any imformation, apparatus, product or process disclosed, or represents that its use would not infringe privately owned rights.

PACIFIC NORTHWEST LABORATORY

operated by

BATTELLE

for the

ENERGY RESEARCH AND DEVELOPMENT ADMINISTRATION

Under Contract E(45-1)-1830

Printed in the United States of America

Available from

Vationa! Technical Information Service

U.S. Department of Commerce

5295 Port Royal Road

Springrield, Virginia 22151

Price: Printed Copy 55.00: Microfiche \$2.25 


\section{POTENTIAL SOURCES FOR THE RADIATION \\ TREATMENT OF FOOD}

by

W. E. Sande and R. A. Libby

August 1976

Battelle

Pacific Northwest Laboratories

Richland, Washington 99352 


\section{ABSTRACT}

A major consideration in the design of large-scale economical food irradiation systems is the radiation source. The "traditional" gamma radiation source, ${ }^{60} \mathrm{Co}$, is presently produced by the irradiation of ${ }^{59} \mathrm{Co}_{0}$ in nuclear reactors. In addition, other radioisotopes with appropriate characteristics for food irradiation systems are presently available or may be available in the future. These radioisotopes are certain waste fission products formed in nuclear reactor fuel during operation. These materials may be separated after the fuel is discharged from the reactor. For example, ${ }^{137} C_{s}$ formed in Hanford reactors is presently being produced in an encapsulated form at the Waste Encapsulation and Storage Facility (WESF) at Hanford, Washington (this facility is operated for ERDA by the Atlantic Richfield Hanford Company). This paper discusses ${ }^{60} \mathrm{Co},{ }^{137} \mathrm{Cs}$, and other potential radiation sources from the standpoint of supply systems, characteristics of the isotopes, encapsulated forms, quantities available, timing of availability, and economics. 


\section{CONTENTS}

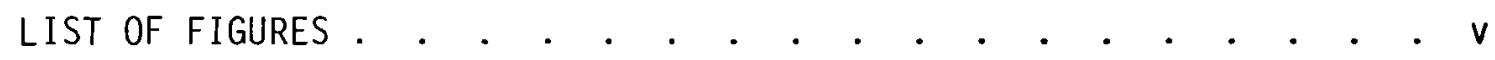

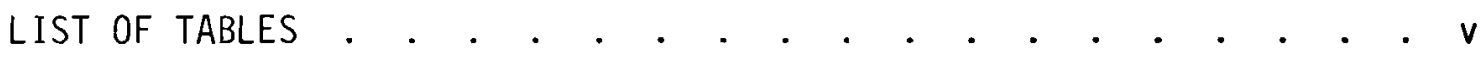

SUMMARY. . . . . . . . . . . . . . . . . . . . . . .

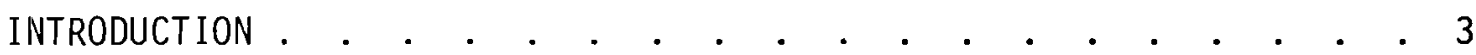

PRESENT AND NEAR-TERM SUPPLY. . . . . . . . . . . . . . . . 3

ELECTRON ACCELERATORS . . . . . . . . . . . . . . . 3

COBALT-60 . . . . . . . . . . . . . . . . . . . 4

CESIUM-137. . . . . . . . . . . . . . . . . . 4

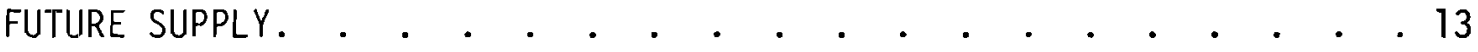

ELECTRON ACCELERATORS . . . . . . . . . . . . . . . . . 13

COBALT-60 . . . . . . . . . . . . . . . . . . .

CESIUMM . . . . . . . . . . . . . . . . . . . . 14

Comparison - Cobalt and Cesium . . . . . . . . . . . 17

OTHER FACTORS. . . . . . . . . . . . . . . . . . 20

CONCLUSION. . . . . . . . . . . . . . . . . . . . . . 21

REFERENCES. . . . . . . . . . . . . . . . . . . 22

DISTRIBUTION . . . . . . . . . . . . . . . . . . Distr-1 


\section{LIST OF FIGURES}

1 WESF Capsule . . . . . . . . . . . . . . . . . . 5

2 Dose Rate from Cesium Chloride Source - Mid Plane. . . . . . 6

3 Dose Rate from Cesium Chloride Source in Water. . . . . . . 7

4 Dose Rate from Cesium Chloride Source in Air . . . . . . . . 7

\section{LIST OF TABLES}

1 Summary of Isotope Source Supply . • . . . . . . . . . . 1

2 WESF Cesium Chloride Capsule Characteristics . . . . . . . . 5

3 Dose Rates from Cesium Chloride Sources . . . . . . . . . 8

4 Cylinder Efficiencies. . . . . . . . . . . . . . . . . . . 9

5 Annular Cylinder Efficiency. . . . . . . . . . . . . 10

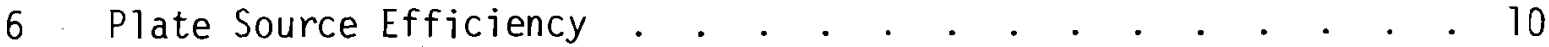

7 Compound Density. . . . . . . . . . . . . . . . . . 11

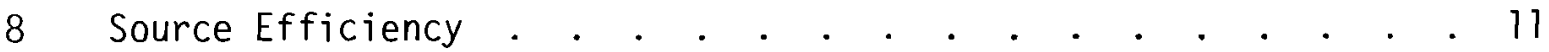

9 Potential ${ }^{60} \mathrm{Co}$ Production. . . . . . . . . . . . . . . . . 14

10 Fuel Reprocessor/Potential Cesium Availability. . . . . . . . 16

11 Potential Yearly Production of Cesium. . . . . . . . . . . 16

12 Radioactive Properties. . . . . . . . . . . . . . . 18

13 Comparison of Equivalent Prices 134-Cs-137Cs

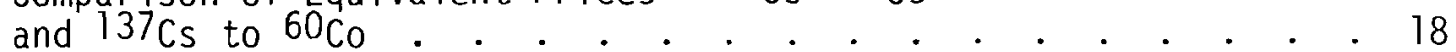


POTENTIAL SOURCES FOR THE RADIATION

TREATMENT OF FOOD (a)

by

W. E. Sande and R. A. Libby

\section{SUMMARY}

The present, near-term, and potential (through year 2000) supply of radiation sources for large-scale radiosterilization applications is discussed in this presentation. Principal sources considered are ${ }^{60} \mathrm{Co}$ produced in nuclear power reactors, ${ }^{137}$ Cs presently available from the nuclear Waste Encapsulation and Storage Facility (WESF) operations at Hanford, and a mixture of ${ }^{134} \mathrm{Cs}-{ }^{137} \mathrm{Cs}$ potentially available from the commercial reprocessing of spent nuclear fuel. Some consideration is also given to "machine" sources (electron accelerator). The principal results for the isotope sources are presented in Table 1.

TABLE 1. Summary of Isotope Source Supply

\begin{tabular}{|c|c|c|c|}
\hline r. & ${ }^{60} \mathrm{CO}$ & ${ }^{137} \mathrm{Cs}$ & ${ }^{134} \mathrm{Cs}-{ }^{137} \mathrm{Cs}$ \\
\hline $\begin{array}{l}\text { Present Production/year } \\
\text { (in North America) }\end{array}$ & $10-15 \mathrm{MCi}$ & $5 \mathrm{MCi}$ & 0 \\
\hline $\begin{array}{l}\text { Near Term } \\
\text {. Production/year }\end{array}$ & $50-150 \mathrm{MCi}$ & $35 \mathrm{MCi}$ & 0 \\
\hline · Lead Time & $1-2 y r$ & $1 y r$ & --- \\
\hline $\begin{array}{c}\text { Potential (year 2000) } \\
\text { Production/year }\end{array}$ & $5,500-16,500 \mathrm{MCi}$ & --- & $\begin{array}{c}1650 \mathrm{MCj} \\
\left(\sim 880 \mathrm{MCi}{ }^{137} \mathrm{Cs}\right)\end{array}$ \\
\hline · Lead Time & $3 y r$ & -- & $5-10 \mathrm{yr}$ \\
\hline
\end{tabular}

Electron accelerators are machines which have essentially a "limitless" supply and a lead time of about 1 to 2 years.

(a) Sponsored by the Nuclear Research and Applications Division of the Energy Research and Development Administration 
A comparison between ${ }^{60} \mathrm{Co},{ }^{137} \mathrm{Cs}$, and ${ }^{134} \mathrm{Cs}-{ }^{137} \mathrm{CS}$ is made based on ${ }^{60} \mathrm{Co}$ price/Ci. To compete as radiation sources, Cs prices may have to be approximately $3 / 4$ the price of ${ }^{60} \mathrm{Co}$ for ${ }^{134} \mathrm{Cs}-{ }^{137} \mathrm{Cs}$ and $1 / 5$ the price of ${ }^{60} \mathrm{Co}$ for ${ }^{137}$ Cs.

At Battelle, Pacific Northwest Laboratories, recent work on ERDA-funded prigrams to evaluate the beneficial use of isotopes has inciuded efficiency and dose calculations of the present WESF ${ }^{137} \mathrm{CS}$ capsule, of other capsule geometries, and of other cesium compounds (cesium chloride, $\mathrm{CsCl}$, is presently available). Results indicate the present capsule (2.06-in. diameter cylinder, 0.2 -in. thick wa11) has an irradiation efficiency of about $60 \%$. This could be increased to about $75 \%$ by going to a $1-i n$. diameter cylinder with $0.1-i n$. thick wal1s. No significant source advantage is apparent from an annular or flat plate geometry. In comparing alternate cesium compounds, (titanate, zeolite, zirconate, and niobate) a titanate was predicted to have the highest dose rate, $83 \%$ of the cesium chloride value. An updated estimate $(1)$ of $\$ 36 \times 10^{6}$ was made for the capital investment for a facility to recover ${ }^{134} \mathrm{Cs}_{5}$ ${ }^{137}$ Cs from nuclear waste by-products produced by a 5 metric tonne heavy metal per day fuel reprocessing plant. Production was about $140 \mathrm{MCi} / \mathrm{yr}{ }^{134} \mathrm{Cs}$ ${ }^{137} \mathrm{Cs}\left(69 \mathrm{MCi}{ }^{137} \mathrm{Cs} / \mathrm{yr}\right.$ ) which could result in a ${ }^{134} \mathrm{Cs}-{ }^{137} \mathrm{Cs}$ price of about $40 \mathrm{C} / \mathrm{Ci}{ }^{137} \mathrm{Cs}$. Reference is made to nuclear waste management factors which should be considered in future analyses of cesium separation. 


\section{INTRODUCTION}

The major radiation sources for large-scale radiosterilization are electron accelerators, cobalt-60 $\left({ }^{60} \mathrm{Co}\right)$, cesium-137 $\left({ }^{137} \mathrm{Cs}\right)$, and a mixture of cesium-137 and cesium-134 ( $\left.{ }^{137} \mathrm{Cs},{ }^{134} \mathrm{Cs}\right)$. Source selection depends strongly on the particular application and on economic considerations. The objective of this paper is to discuss present, near-term, and potential supply of irradiation sources, and to present work recently completed at Battelle, Pacific Northwest Laboratories on cesium sources. The emphasis will be placed on cobalt and cesium gamma sources and on electron accelerators. For those interested in more detailed information on economic comparisons between sources and analyses of specific applications, see References 2 though 9.

Knowledge of present, near-term, and potential supply is considered important in order to anticipate what radiation sources would be available if radiation sterilization applications were suddenly increased, (i.e., both food and sewage sterilization were undertaken on a large scale).

\section{PRESENT AND NEAR-TERM SUPPLY}

The sources available for present or near-term use include electron accelerators, ${ }^{60}$ Co and ${ }^{137}$ Cs. Recently, nuclear spent fuel elements have also been considered as radiation sources for sterilization, ${ }^{(3)}$ but the complex radiation spectrum and rapid-variable decay from mixed fission products probably should eliminate this source from further consideration for food treatment (which requires uniform dose).

\section{ELECTRON ACCELERATORS}

Electron accelerators are currently available from a number of manufacturers. $(10)$ Recent literature $(2,6,9)$ provides pricing and characteristic information which indicates that these "machines" are economically competitive with other sources in specific applications; certain characteristics such as low penetration of electrons may limit their use. The alternative of combining an electron accelerator with a heavy metal target to produce $X$-rays gives greater penetration but the efficiency of conversion is relatively low. 
In terms of supply, electron accelerators are custom built at this time and are available from about 6 months to 1 yr after order. Thus, a sudden increase in demand in the near future could probably be met with less than a $2-y r$ lead time with this radiation source. $(2,6,9)$

\section{COBALT -60}

Currently, ${ }^{60}$ Co is available from three suppliers in North America: Atomic Energy of Canada Limited - Commercial Products, Ottawa, Canada; Neutron Products Inc. - Dickerson, Maryland; and General Electric Nuclear Energy Division - Pleasanton, California. Total annual production is presently 10 to $15 \mathrm{MC} i$ with the four CANDU reactors at Pickering, Ontario having a production capability of $10 \mathrm{MCi} / \mathrm{yr}$ which could be increased to $50 \mathrm{MCi}$ by future Canadian power reactors. (11) However, any immediate increase from the present 10-MCi capacity would probably require several years lead time. This is also true for other potential ${ }^{60}$ Co production from existing power reactors.

Present price of ${ }^{60} \mathrm{CO}$ is between $40 \phi$ and $60 \$ / \mathrm{Ci}$; the price tends to fall as size of order increases.

\section{CESIUM-137}

The Hanford Waste Encapsulation and Storage Facility (WESF) operated for ERDA by the Atlantic Richfield Hanford Company (ARHCO) is presently producing encapsulated ${ }^{90} \mathrm{SrF}_{2}$ and ${ }^{137} \mathrm{CSCl}$ recovered from the reprocessing of fuel from the Hanford Plutonium Production Reactors; an updated review of this facility and its products will soon be available. (12) Currently, the WESF is the major source of ${ }^{137} \mathrm{CS}$ in large quantities. The cesium capsule assembly, a double walled stainless steel cylinder, is shown in Figure 1 while the capsule characteristics are presented in Table 2.

Due to the age of the nuclear waste, the radioactive cesium is essentially a $11{ }^{137}$ Cs. The WESF began operation with radioactive material in September 1974. As of April 1976 about 120 capsules (8.4 MCi) had been produced. After process modifications are made projected production rate is 42 capsules/month which 


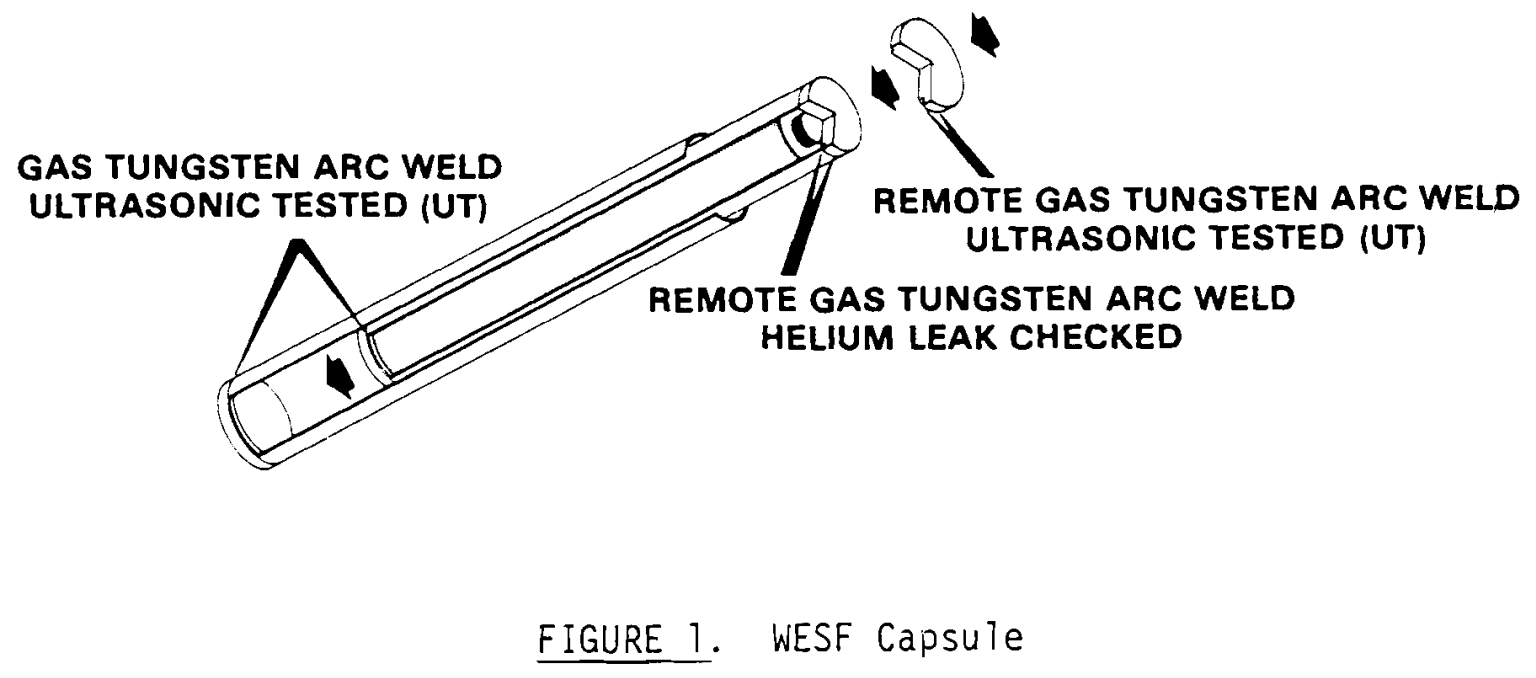

TABLE 2. WESF Cesium Chloride Capsule Characteristics

\begin{tabular}{|c|c|}
\hline DIMENSIONS & \\
\hline Inner Capsule: & $\begin{array}{l}\text { 316-L stainless steel } \\
0.095-\text { in. wal1 thickness } \\
2.250-\text { in. outside diameter } \\
19.725-\text { in. total length } \\
0.400-\text { in. total cap thickness }\end{array}$ \\
\hline Outer CapsuTe: & $\begin{array}{l}\text { 316-L stainless steel } \\
0.109-i n . \text { wall thickness } \\
2.625-i n . \text { outside diameter } \\
20.775-i n \text {. total length } \\
0.400-i n \text {. total cap thickness }\end{array}$ \\
\hline DENSITY & $2.47 \mathrm{~g} / \mathrm{cm}^{3}$ \\
\hline QUANTITY OF ${ }^{137} \mathrm{CS}$ & $48-49 w t \%$ \\
\hline IMPURITIES & $4-6 w t \%$ \\
\hline HEAT GENERATION & 300 watts \\
\hline RADIOACTIVITY & $70,000 \mathrm{Ci}{ }^{137} \mathrm{Cs}$ \\
\hline
\end{tabular}

will provide about $35 \mathrm{MC} i$ of ${ }^{137} \mathrm{Cs} / \mathrm{yr}$. The facility will operate until a 17 of the Hanford ${ }^{137} \mathrm{CS}$ is encapsulated ( 110 to $140 \mathrm{MC}$ ). The U.S. Government is selling its inventory of cesium for $10 \notin / C i$ not including incrementa 7 hand ling and shipping charges. 
It should be noted that the purpose of the WESF facility is to safely store strontium and cesium; the present capsules and product forms are designed for such. For ${ }^{137}$ Cs use as a radiation source, modification of the capsule size, geometry, and product form may have advantages. In support of ongoing ERDA programs at Sandia Laboratories and Battelle-Pacific Northwest Laboratories (PNL) concerning the beneficial use of by-product isotopes, source efficiency studies have been made at PNL for various ${ }^{137}$ Cs irradiators. This included: 1) calculation of efficiency and dose rate for the current WESF design, 2) comparison of the calculated and measured dose rates, 3) calculation of the effect of changes in geometry on efficiency, and 4) estimation of efficiencies and surface dose rates for cesium compounds other than cesium chloride.

The point kernel computer code QAD-P5A ${ }^{(13)}$ was used to determine dose rates and efficiencies. The calculated dose rates from the present WESF capsule are indicated in Figures 2 to 4 . In Figure 2 the dose rate in air and water is plotted for radial distances up to $100 \mathrm{~cm}$ from the center line of the source. In Figures 3 and 4 the dose rates are plotted along several axial traverses, again in both water and air.

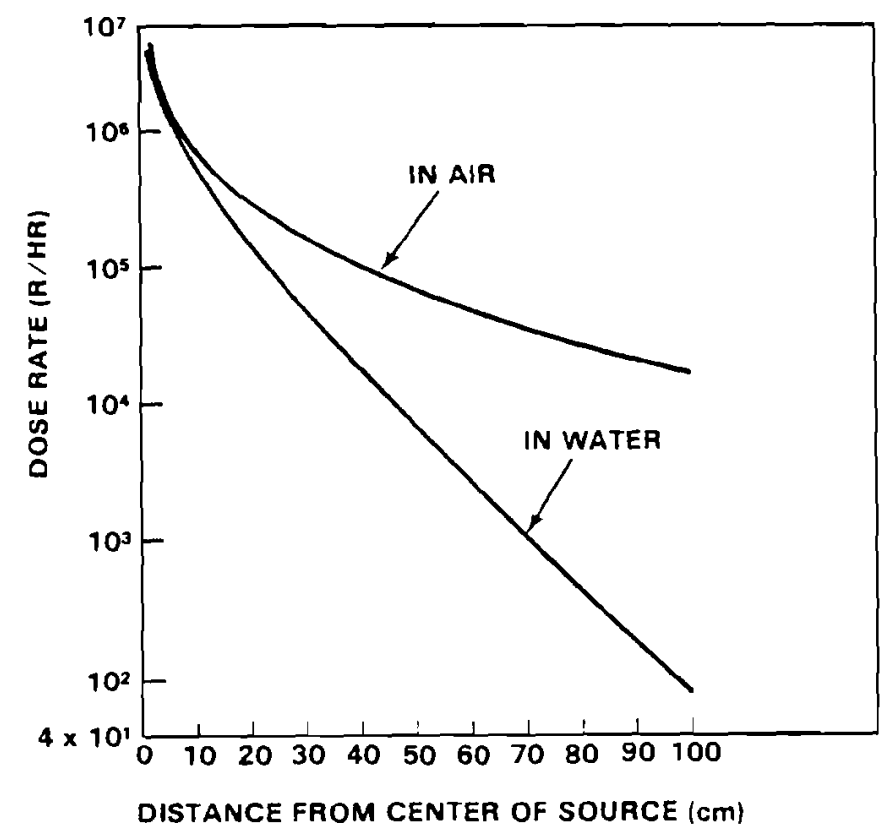

FIGURE 2. Dose Rate from Cesium Chloride Source - Mid Plane 


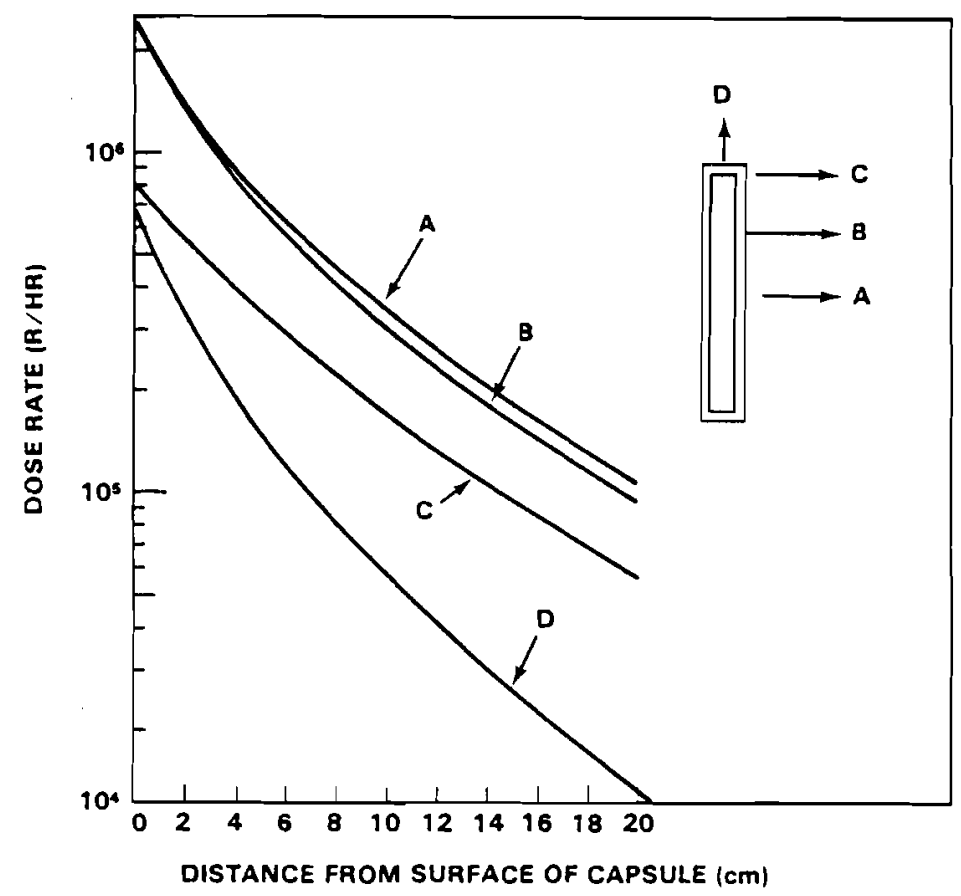

FIGURE 3. Dose Rate from Cesium Chloride Source in water

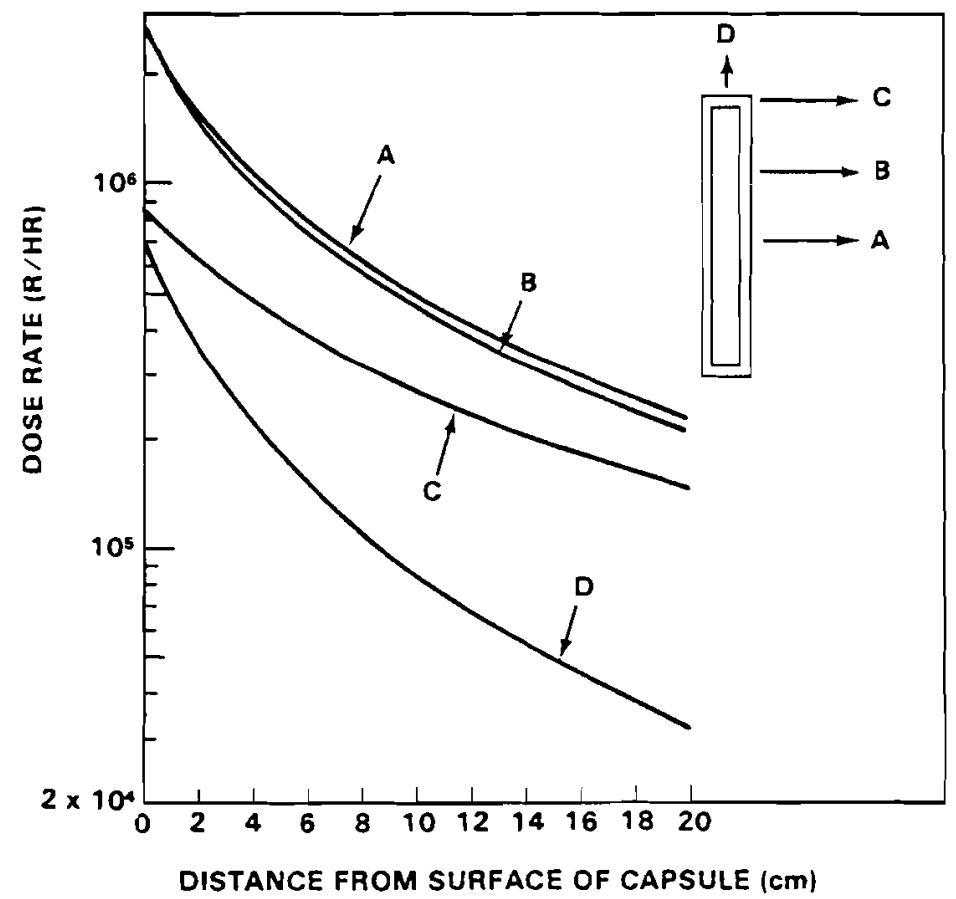

FIGURE 4. Dose Rate from Cesium Chloride Source in Air 
Dosimetry measurements performed on one of the WESF cesium chloride capsules agree quite well with the calculated dose rates. The experimental dose rates are listed in Table 3 along with the calculated values from Figure 2. Due to the interpolation required for the $50-\mathrm{cm}$ value, a $10 \%$ error is possible at this point. The experimental values should be within 10\%. The QAD-P5A results were also compared with $\mathrm{ARHCO}^{(14)}$ calculations, and the Cesium Data Sheets. (15) These comparisons yielded good agreement which indicates that the code is correctly calculating the dose rates for these capsules.

TABLE 3. Dose Rates from Cesium Chloride Sources

$\begin{array}{lccc}\begin{array}{l}\text { Distance from } \\ \text { Surface of }\end{array} & & \\ \text { Source, cm } & \text { Measured, R/hr } & & \text { Calculated, R/hr } \\ 20 & & 302,000 & \\ 30 & 168,900 & & 160,000 \\ 50 & 55,300 & 68,000\end{array}$

The calculated dose rates presented so far include a term called the "buildup factor." This term is defined as the ratio of the dose rate (or energy absorption) due to the total gamma ray flux density at a point to the dose rate (or energy absorption) due to the uncollided gamma ray flux density at the same point. This factor multiplied by the uncollided flux density accounts for the increase in flux density due to scattered gamma rays. Due to the agreement between the measured and calculated dose rates for the WESF capsule, the efficiencies of other geometries and compounds were calculated using the buildup factor. For these calculations efficiency is defined as the ratio of the dose rate with attenuation in the source and clad to the dose rate without attenuation in the source and clad. Since the energy of scattered gammas is lower than unscattered gammas, the actual efficiencies may be 5 to $10 \%$ less than those reported.

The source geometry parameters which influence the efficiency include the diameter, wall thickness, and shape. An analysis was made to ascertain the potential benefits of changing WESF capsule design. Included in this analysis were: 1) the effect of wall thickness and diameter for a cylindrical source, 2) the effect of an annular cylindrical source, and 3) the effect of a plate source. 
The efficiencies for cylinders with various radii and clad thicknesses are listed in Table 4. The highest efficiencies are possible with cylinders having the smallest diameter and the thinnest wall. However, since the number of capsules required for a given volume of compound varies inversely with the square of the diameter, an effective lower limit is reached for the smallest practical diameter. In addition, fabrication and source handling are easier with a few large sources rather than a large number of small irradiators. Evaluation of these factors indicates that the cost effective design is a cylinder with a diameter of approximately 1 in. with 0.1 -in. wall thickness.

\section{TABLE 4. Cylinder Efficiencies}

\begin{tabular}{|c|c|c|c|}
\hline \multicolumn{2}{|c|}{ Source } & \multirow[b]{2}{*}{ Efficiency, $\%$} & \multirow[b]{2}{*}{$\begin{array}{c}\text { Efficiency } \\
\text { Increase Over } \\
\text { Present Design, } \% \\
\end{array}$} \\
\hline $\begin{array}{l}\text { CsCl Diameter, } \\
\text { in. }\end{array}$ & $\begin{array}{c}\text { Wal1 } \\
\text { Thickness, } \\
\text { in. }\end{array}$ & & \\
\hline 2.06 & 0.204 & 60 & \\
\hline 2.06 & 0.100 & 69 & 15 \\
\hline 1.0 & 0.100 & 77 & 28 \\
\hline 1.0 & 0.204 & 67 & 12 \\
\hline 0.5 & 0.204 & 71 & 18 \\
\hline
\end{tabular}

Due to the reduction in self shielding which would be possible with an annular cylinder source geometry, calculations were also made for annular cylinders (2.625-in. 00, 0.2-in. clad); these results are summarized in Table 5. Apparently no increase in efficiency is achieved by using an annular geometry. This is probably due to an increase in the absorption in the wall from the larger wall-to-source volume ratio with thin annular regions.

Calculations for a plate source geometry, summarized in Table 6 , are based on a 40-cm square plate with a 0.1-in. SS wall thickness. The edge effects for the finite-sized geometry are more important for plate sources than for cylinders. The value at the clad surface approximates the efficiency 
TABLE 5. Annular Cylinder Efficiency

$\begin{array}{cc}\begin{array}{c}\text { Radial } \\ \text { Thickness, in. } \\ \hline 1.0\end{array} & \frac{\text { Efficiency, \% }}{60} \\ 0.5 & 60 \\ 0.3 & 61 \\ & \\ \text { TABLE 6. Plate Source Efficiency } \\ \text { Source } \\ \text { Thickness, cm } \\ 0.5 & \\ 1.0 & 58 \\ 2.0 & 59\end{array}$

at any location for an infinite plate source. Since any practical irradiator will be finite in size with a limiting distance over which irradiation will occur, these efficiency values are reasonable lower limits. Compared with cylindrical sources, the efficiencies are lower, thus no significant gains are realized by switching to a plate source geometry.

Sandia Laboratories has an ongoing program concerning the "thermoradiation" of sewage sludge using radioactive cesium. $(16,17)$ Due to the high solubility of cesium chloride in water, considerable interest has been generated in the use of other compounds for irradiator sources. The compounds of interest include ceramics and a zeolite. Table 7 lists the compounds of interest, the bulk density, and the cesium density for each. The bulk densities are from a Sandia Laboratory report ${ }^{(16)}$ except for cesium chloride which is from ARHCO estimates for the WESF capsule.

Table 8 lists the efficiencies and dose rates at the clad surface for sources of the various compounds. The source geometry is the same for all compounds (diameter of $1.0-i n$. with $0.1-$ in. SS clad) the highest efficiency 
TABLE 7. Compound Density

\begin{tabular}{|c|c|c|}
\hline \multirow[b]{2}{*}{ Compound } & \multicolumn{2}{|l|}{ Density } \\
\hline & 9 compound $/ \mathrm{cm}^{3}$ & $\mathrm{~g} \mathrm{Cs} / \mathrm{cm}^{3}$ \\
\hline $\mathrm{Cs}_{2} \mathrm{Ti}_{4} \mathrm{O}_{9}$ & 4.0 & 1.8 \\
\hline $\mathrm{Cs}_{2} \mathrm{Nb}_{4} \mathrm{O}_{11}$ & 4.7 & 1.6 \\
\hline $\mathrm{Cs}_{2} \mathrm{Zr}_{4} \mathrm{O}_{9}$ & 4.5 & 1.6 \\
\hline $\mathrm{Cs}_{8}\left[\mathrm{Al}_{8} \mathrm{Si}_{40}{ }^{0}{ }_{96}\right]$ & 2.5 & 0.7 \\
\hline $\mathrm{CsCl}$ & 2.47 & 1.96 \\
\hline
\end{tabular}

TABLE 8. Source Efficiency

\begin{tabular}{|c|c|c|}
\hline Compound & Efficiency, \% & $\begin{array}{l}\text { Dose Rate, R/hr } \\
\text { At Clad Surface }\end{array}$ \\
\hline $\mathrm{Cs}_{2}{ }^{\top}{ }^{i}{ }_{4}{ }_{9}$ & 72 & $1.46 \times 10^{6}$ \\
\hline $\mathrm{Cs}_{2} \mathrm{Nb}_{4} \mathrm{O}_{11}$ & 69 & $1.26 \times 10^{6}$ \\
\hline $\mathrm{Cs}_{2} \mathrm{Zr}_{4} \mathrm{O}_{9}$ & 70 & $1.28 \times 10^{6}$ \\
\hline $\mathrm{Cs}_{8}\left[\mathrm{Al}_{8} \mathrm{Si}_{40} \mathrm{O}_{96}\right]$ & 77 & $0.62 \times 10^{6}$ \\
\hline $\mathrm{CsCl}$ & 77 & $1.76 \times 10^{6}$ \\
\hline
\end{tabular}

occurs with zeolite and cesium chloride. In all cases the dose rate is normalized to the present WESF cesium content. In comparing these dose rates, the titanate has the highest surface dose rate except for cesium chloride. The low cesium density in the $\mathrm{Cs}_{8}\left(\mathrm{Al}_{8} \mathrm{Si}_{40}{ }_{96}\right)$ zeolite reduces the dose rate considerably and thus would require many additional sources for the same level of irradiation.

More information on 111 of the previously discussed source efficiency calculations can be found in a recent PNL report. (18)

The present WESF capsule and chloride form may be suited as a radiation source. However, if future safety and market analyses indicated a needed change in source size and compound, a limited number of "new" sources could 
be made available for testing and demonstration purposes. The WESF product could be modified at Oak Ridge National Laboratory, Oak Ridge, Tennessee. The customer would have to pay for any increased cost. Then, an analysis could be made to determine if a major change in WESF operation is economically justifiable. 


\section{FUTURE SUPPLY}

Projecting relatively long-term supplies of radiation sources (from the year 1980 to 2000) is highly uncertain and quite dependent on the assumptions used. It does, however, give an idea of what might be available from various suppliers within possible limits, e.g., maximum use of future power reactors for ${ }^{60}$ Co production and maximum recovery of cesium from reprocessing nuclear spent fuel elements. The quantities available for gamma radiation would be much larger than present demand, but if one takes for an example the "thermoradiation" process which Sandia Laboratories $(16,17,19)$ is studying and includes the potential requirements for food irradiation, the quantities required through the year 2000 may not be too far from future production.

\section{ELECTRON ACCELERATORS}

Electron accelerators have the limits, mentioned previously, of low radiation penetration and cannot compete with gamma radiation in every application unless the less efficient conversion to $X$-rays is made. This radiation source has the advantage of being a machine amenable to production line economics and limited by relatively short lead times. Thus, the potential supply of accelerators is essentially limitless and dependent on market demand. A major technological advance in conversion efficiency from electron to $X$-ray production could make these "machines" competitive in almost every application (except those requiring high gamma energy radiation such as teletherapy where high specific activity ${ }^{60}$ Co is used).

\section{COBALT -60}

Cobalt production depends on the willingness of nuclear power reactor operators to irradiate ${ }^{59} \mathrm{Co}_{0}$ in the core of their reactors. This results in reactor fuel cycle penalties of down time (loss of power production) for source removal and loading, and lower fuel burnup or higher fuel enrichment to accommodate the cobalt poison. ${ }^{(21)}$ Other costs would be in source fabrication, shipping, and encapsulation. Further, large-scale production would 
require additional hot cell facilities for encapsulation of the irradiated material. However, one facility could be used to process ${ }^{60}$ Co from many reactors. The only other limit is the construction of the power reactors themselves.

Cobalt production could possibly expand to about 10 to $30 \mathrm{MCi} / \mathrm{yr}$ (23 $\mathrm{Ci} / \mathrm{g}$ specific activity) in a $1000 \mathrm{MWe}{ }^{(21)}$ pressurized water reactor. Assuming use of the total projected nuclear generating capacity, the potential production of ${ }^{60} \mathrm{Co}$ is shown in Table 9 assuming 2 -year lead time between reactor start-up before initial loading of ${ }^{59} \mathrm{Co}$ and 1 -year irradiation time.

TABLE 9. Potential ${ }^{60}$ Co Production (a)

\begin{tabular}{|c|c|c|c|}
\hline Year & $\mathrm{GWe}^{(\mathrm{b})}$ & $\mathrm{MCi}$ & ${ }^{60} \mathrm{Co}$ \\
\hline 1980 & 50 & 500 & $=1,500$ \\
\hline 1985 & 110 & 1,100 & $-3,300$ \\
\hline 1990 & 230 & 2,300 & $-6,900$ \\
\hline 1995 & 480 & 4,800 & $-14,400$ \\
\hline 2000 & 550 & 5,500 & $-16,500$ \\
\hline
\end{tabular}

(a) Basis: 10-30 MCi/yr/1000 MWe, 2-year lead time between reactor start-up and insertion of $59 \mathrm{Co} / \mathrm{yr}, 1$ year irradiation time, specific activity $23 \mathrm{Ci} / \mathrm{g}$.

(b) Technical Al ternatives Document (Draft), Reference 22.

\section{CESIUM}

Cesium is potentially available in the future from reprocessing spent nuclear fuel elements. Reprocessing spent fuel involves separation and recovery of about $99 \%$ of the uranium and plutonium from the fuel cladding and the products formed during nuclear fission. The separated uranium and plutonium will be recycled into new fuel elements. The remaining fission products (including cesium), actinides, and fuel cladding is termed "nuclear waste" which must be isolated due to its toxicity. 
The present objective of the nuclear industry is to close the nuclear fuel cycle by providing fuel reprocessing capability and demonstrating safe nuclear waste storage. The present direction concerning the waste fission products is to solidify them within 5 years after separation. The solidified form will likely be a borosilicate glass (with a low leachability) placed in 12 to 24-in. diameter, 10- to 15-ft long stainless steel canisters. The cesium could be recovered from the waste by a chemical separations plant before solidification.

The characteristics of the cesium depends on the burnup, power level, and the period since irradiation of the fuel (time out of reactor). Relatively fresh cesium will contain ${ }^{137} \mathrm{CS}$ as well as an appreciable amount of ${ }^{134} \mathrm{Cs}$ which has a half-life of 2.1 years. The presence of ${ }^{134} \mathrm{Cs}$ increases the total cesium specific activity but increases the decay rate. The net effect is an increase in the value of the cesium as an irradiation source. Only a few years delay in cesium recovery can cause a significant decrease in this value.

Table 10 shows the various existing and planned fuel reprocessing plants and their potential to supply cesium based on 25,000 MWd/MTHM(a) boiling water reactor fuel and 1 -year old waste (out-of-reactor). This latter assumption may be optimistic since for the first 5 to 10 years of reprocessing, the waste may not be less than 2 years old due to spent fuel backlog. Table 11 presents potential cesium availability as a function of time. Factors which influence the availability of separated cesium are a lead time of about 5 to 10 years between the decision to separate cesium and actual production, and the present plans to use up to 5000 solidified waste canisters for pilot plant studies of permanent disposal methods. It is unlikely any plans for permanent disposal studies would include cesium separation since the radiation characteristics of the waste would be significantiy changed and the prime objective is to show the safe disposal of all the waste. After safe permanent disposal is assured, the cesium would be available for separation.

(a) Megawatt-day/metric tonne heavy metal. 
This could mean cesium would not be available until 1986. The dotted line represents the date after which it is expected (at this time) that the first cesium from commercial fuel reprocessing would be available for use in irradiation. Total accumulation of separated ${ }^{137} \mathrm{Cs}$ in the year 2000 could be about 8,000 to $11,000 \mathrm{MCi}{ }^{137} \mathrm{Cs}$ (according to Reference 20 modified by the schedules in Table 11).

TABLE 10. Fuel Reprocessor/Potential Cesium Availability(a)

\begin{tabular}{|c|c|c|c|c|}
\hline & $\operatorname{AGNS}^{(b)}$ & $\mathrm{NFS}(\mathrm{c})$ & Exxon & $\begin{array}{c}\text { New } \\
\text { Capacity }\end{array}$ \\
\hline MTHM/yr & 1500 & 600 & 1500 & 1000 \\
\hline Startup Date & 1979 & 1983 & 1985 & 1988 \\
\hline T3/ Cs, MCi/yr & 120 & 50 & 120 & 80 \\
\hline${ }^{134} \mathrm{Cs}-{ }^{137} \mathrm{Cs}, \mathrm{MCi} / \mathrm{yr}$ & 230 & 90 & 230 & 150 \\
\hline
\end{tabular}

(a) Basis: 25,000 MWd/MTHM, BWR fuel, 1-year old fuel. (4)

(b) All ied-General Nuclear Services, Barnwel1, South Carolina.

(c) Nuclear Fuel Services, West Valley, New York.

TABLE 11. Potential Yearly Production of Cesium $(a)$

\begin{tabular}{|c|c|c|c|}
\hline & $\begin{array}{l}\text { LWR Fuel } \\
\text { Reprocessed } \\
\text { (MTHM) } \\
\end{array}$ & $\begin{array}{c}M C i \\
137 C_{S} \\
\end{array}$ & $\begin{array}{c}M C j \\
134 C s-137 C s \\
\end{array}$ \\
\hline 1980 & 1,000 & 80 & 150 \\
\hline $\begin{array}{l}1985 \\
1990^{-}\end{array}$ & $-\frac{2,600}{5,000}$ & $-\frac{210}{400}-$ & $-\frac{400}{750}-$ \\
\hline 1995 & 8,500 & 680 & 1,300 \\
\hline 2000 & 11,000 & 880 & 1,650 \\
\hline
\end{tabular}

(a) Basis: 25,000 MWd/MTHM, BWR fuel, 1 year old fuel. See Reference 4. Full production after 2 years from startup, modified startup schedule applied to information in Reference 22. 
Comparison - Cobalt and Cesium

A detailed comparison between the economics of using cesium was made by McKee ${ }^{(4)}$ who included an analysis of the relative values of ${ }^{137} \mathrm{Cs}$ and ${ }^{134} \mathrm{Cs}$ ${ }^{137} \mathrm{Cs}$ sources compared to ${ }^{60}$ Co sources. (a) Since bulk or packaged materials would be treated in many potential gamma irradiation applications, gamma energy intensity is not a controlling factor in facility design; a prime factor is total dose. The dose uniformity from cobalt and cesium sources is similar, thus the cesium and cobalt sources were assumed to be equivalent when their emitted gamma energy productions were equal. Other factors which were considered in McKee's analysis were source replenishment schedules, capsule sizes and efficiencies, cesium age, source salvage value, etc. For example, the required yearly source replenishment (in curie \%) for a 1-MCi ${ }^{60} \mathrm{Co}$ reference source (which would compare to a ${ }^{134} \mathrm{Cs}-{ }^{137} \mathrm{Cs}$ source of $1.33 \mathrm{MCi}$ ${ }^{137} \mathrm{Cs}$ in the first year to $2.4 \mathrm{MCi}{ }^{137} \mathrm{Cs}$ in the seventh year and would be equivalent to a ${ }^{137} \mathrm{Cs}$ source of $4.2 \mathrm{MCi}{ }^{137} \mathrm{Cs}$ ) approaches an equilibrium value of $15 \%$ for ${ }^{60} \mathrm{Co}$, is $2.3 \%$ for ${ }^{137} \mathrm{Cs}$, and approaches an equivalent value of $18 \%$ for ${ }^{134} \mathrm{Cs}-{ }^{137} \mathrm{Cs}$. The yearly replenishment amount is higher for the ${ }^{134} \mathrm{Cs}-{ }^{137} \mathrm{Cs}$ source than the ${ }^{137} \mathrm{Cs}$ source due to the shorter half-life of ${ }^{134} \mathrm{Cs}$. Facility size for the ${ }^{60} \mathrm{Co}$ and ${ }^{134} \mathrm{Cs}-{ }^{137} \mathrm{Cs}$ were assumed to be approximately equal. For the ${ }^{137}$ Cs the facility would be larger, however the increased cost was assumed to be balanced by lower shielding requirements. The results were presented in relation to $40 \notin / \mathrm{Ci}{ }^{60} \mathrm{Co}$; these can be modified to apply to other ${ }^{60}$ Co prices by multiplication using the ratio of ${ }^{60} \mathrm{Co}$ prices. For example, the results indicate the equivalent price of ${ }^{137} \mathrm{Cs}$ to $40 \$ / \mathrm{Ci}{ }^{60} \mathrm{Co}$ is $8.24 / \mathrm{Ci}$ ${ }^{137} \mathrm{Cs}$, thus the equivalent price for ${ }^{137} \mathrm{Cs}$ to $30 \notin / \mathrm{Ci}{ }^{60} \mathrm{Co}$ is $8.2 \times(30 / 40)$ or $6.2 \notin / \mathrm{Ci}{ }^{137} \mathrm{Cs}$. The equivalent cesium prices to various ${ }^{60} \mathrm{Co}$ prices are presented in Table 13. The range of cesium prices are due to uncertainties in waste age, salvage value, return on investment, and source diameter. The base values represent what was considered to be the most likely price according to the assumptions.

An update (based on the ${ }^{244} \mathrm{Cm}$ recovery plant in Reference 22) of the capital investment required for a cesium recovery plant was recently made at PNL. (1) The concept is an add-on facility to a 5-metric tonne heavy metal per day fuel reprocessing plant. The bases were $69 \mathrm{MCi} / \mathrm{yr}{ }^{137} \mathrm{Cs}$ production, (50\%)

(a) Some of the radioactive properties of these isotopes are presented in Table 12. 
TABLE 12. Radioactive Properties (4)

\begin{tabular}{|c|c|c|c|}
\hline & ${ }^{134} \mathrm{Cs}$ & ${ }^{137} \mathrm{Cs}$ & ${ }^{60} \mathrm{CO}$ \\
\hline Half-life, yr & 2.10 & 30.2 & 5.26 \\
\hline Activity, $\mathrm{Ci} / \mathrm{g}$ & 1271 & 86.5 & 1131 \\
\hline \multicolumn{4}{|l|}{$\begin{array}{l}\text { Decay Energy, } \\
\mathrm{W} / \mathrm{Ci}\end{array}$} \\
\hline$\overline{\text { Gamma }}$ & $9.48 \times 10^{-3}$ & $3.35 \times 10^{-3}$ & $14.9 \times 10^{-3}$ \\
\hline Beta & $0.85 \times 10^{-3}$ & $1.0 \times 10^{-3}$ & $0.56 \times 10^{-3}$ \\
\hline \multicolumn{4}{|l|}{$W / g$ (pure) } \\
\hline Gamma & 12.05 & 0.29 & 16.8 \\
\hline Beta & 1.08 & 0.084 & 0.64 \\
\hline
\end{tabular}

TABLE 13. Comparison of Equivalent Prices $134 \mathrm{Cs}-137 \mathrm{Cs}$ and $137 \mathrm{Cs}$ to $60 \mathrm{Co}(4)$

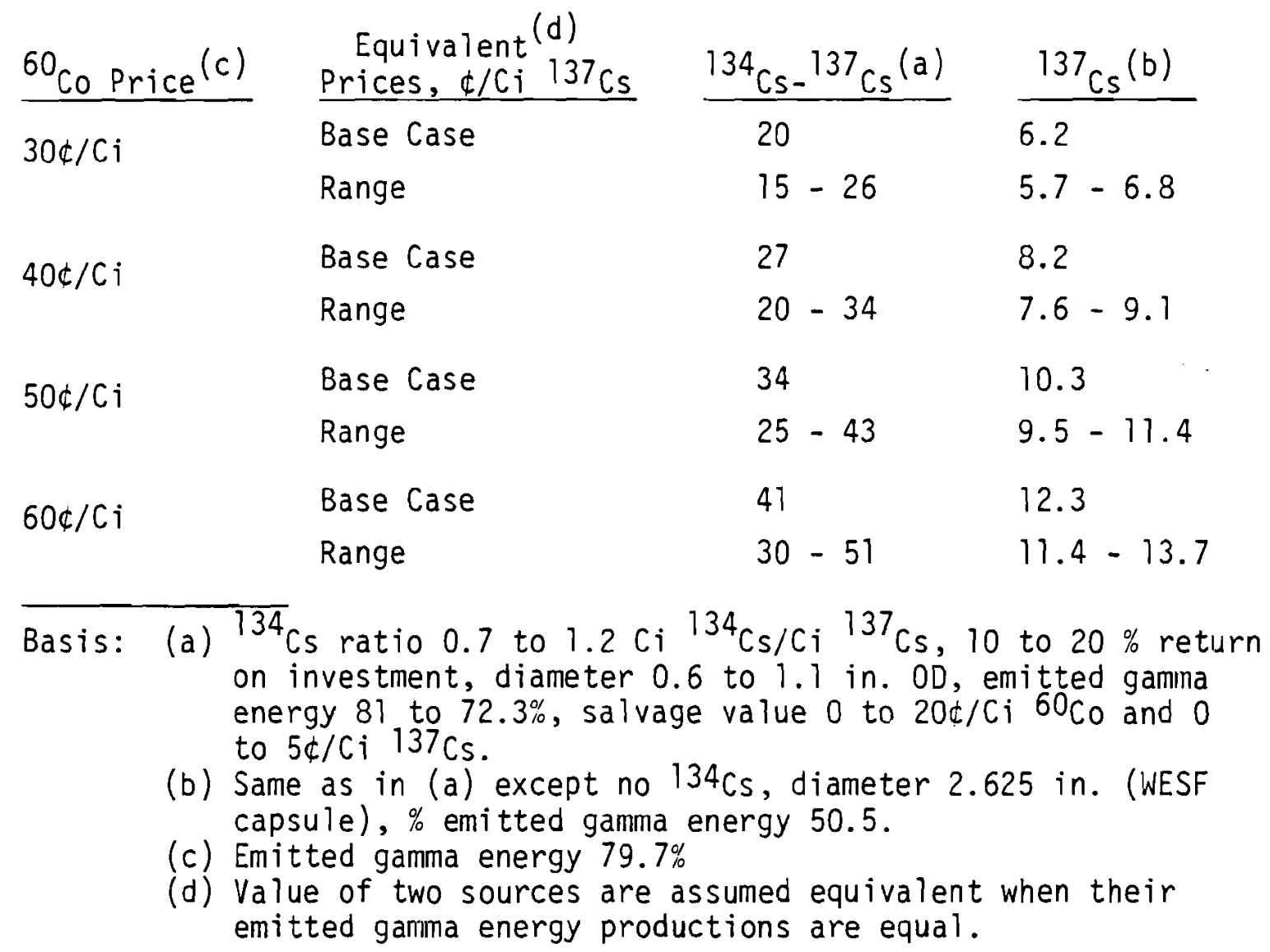


recovery of total available) 10-year project, $15 \%$ return on investment, $10 \%$ interest rate, sales of $100 \%$ plant operating capacity, expense of about $\$ 6 \times 10^{6} / \mathrm{yr}$, and a capital investment of roughly $\$ 36 \times 10^{6}$. These would require a ${ }^{137} \mathrm{Cs}$ price of $40 \$ / \mathrm{Ci} ;{ }^{60}$ Co prices should have a value between $50 \$$ and $90 \$ / \mathrm{C} i$ to allow $40 \$ / \mathrm{C}$ cesium from this plant to compete economically. If an integrated plant that could recovery both cesium and strontium $\left({ }^{90} \mathrm{Sr}\right.$ has commercial potential as a heat source) were built for $\$ 50 \times 10^{6}$ and yearly sales were $100 \%$ of plant capacity $\left(69 \mathrm{MCi} / \mathrm{yr}{ }^{137} \mathrm{Cs}\right.$ and $51 \mathrm{MCi} / \mathrm{yr}{ }^{90} \mathrm{Sr}$ which is $50 \%$ of the total available), the prices would be $30 \$ / \mathrm{Ci}{ }^{137} \mathrm{Cs}$ and $40 \$ / \mathrm{Ci}{ }^{90} \mathrm{Sr}$ (assuming $50 \%$ sales volume for both ${ }^{137} \mathrm{Cs}$ and ${ }^{90} \mathrm{Sr}$ ). This cesium price could possibly compete with ${ }^{60} \mathrm{Co}$ priced between $30 \notin$ and $50 \$ / \mathrm{Ci}$. The preceding prices for $\mathrm{Cs}$ and $\mathrm{Sr}$ are based on 50\% recovery of total available; increased recovery efficiency could reduce these prices. Other waste fission products which have potential for beneficial uses (i.e., ${ }^{244} \mathrm{Cm},{ }^{241} \mathrm{Am}, \mathrm{Np},{ }^{147} \mathrm{Pu}$, Ru $\mathrm{Rh}$, and $\mathrm{Pd}$ ) could be recovered with a more complex plant; this could lower the cesium price further depending on the market, incremental costs, etc. Based on these considerations, apparent factors which could make the future recovery of cesium by private industry more likely are (assuming a large increase in gamma source demand):

- an increase in ${ }^{60}$ Co price,

- existence of a market for other fission products, and

- reprocessing of relatively fresh fuel, less than 2 yr old (more ${ }^{134}$ Cs recovered).

The preceding analys is has limits which make the results uncertain, but it is an example of what prices might be needed for a profitable plant in today's economic climate. 


\section{OTHER FACTORS}

Future detailed analyses of large-scale fission product utilization should consider the effect on nuclear waste management. Recent work (23) indicates removing cesium, strontium, and any portion of nuclear waste for special treatment may not have any safety advantage In the case of cesium and strontium, their short half-lives and retention (sorption) by geologic media greatly reduce their long-term risk when placed in geologic isolation. Thus, if permanent disposal is satisfactory for several hundred years, the risk from strontium and cesium becomes much less. Even if release began in the year 2000, cesium and strontium may not be a problem for a "reasonable" site. On another basis, the separation and concentration of cesium and strontium and not permanent disposal until after use may increase its shortterm risk to man. There exists the option of separation and being able to closely monitor cesium and strontium for an initial period or of putting it in permanent disposal where it would not be as closely monitored. Examples of other factors which should receive consideration are:

- How would the separated cesium and strontium be permanentiy disposed and what would the costs be?

- Would the generation of large quantities of ${ }^{60}$ Co versus cesium (which is a waste and would be already available) cause increased waste management costs?

- Would the complete separation and use of cesium and strontium offer waste management savings by allowing larger diameter canisters (decreased heat load) and by decreasing canister handling and transportation costs (lower radiation dose)? Note: Volume reduction would only be on the order of 5 to $10 \%$. 


\section{CONCLUSION}

In any specific analysis of a radiation application, consideration should be given to electron accelerators, ${ }^{60} \mathrm{Co}$, and cesium sources. Cesium-137 is precently available from the Hanford WESF operation as cesium chloride. If necessary, this form could be modified to produce experimental and demonstration quantities of other cesium compounds and/or modified source geometries. Future large-scale demand for radiation sources could be supplied depending on the specific application by electron accelerators, electron accelerator $X$-ray machines, ${ }^{60} \mathrm{Co}$ from power reactors, or ${ }^{134} \mathrm{Cs}-{ }^{137} \mathrm{Cs}$ from nuclear waste. In analyzing the market for these latter radioisotope sources, some consideration should be given to the effects of their use as radiation sources on nuclear waste management. 


\section{REFERENCES}

1. J. A. Partridge and 0. H. Koski, Selection and Evaluation of Processes for Recovery of Beneficial Isotopes from Commercial Reactor Wastes, BNWL-2063, Battelle-Northwest, Richland, WA (In Publication), 1976.

2. D. S. Ballantine, "Alternative High-Level Radiation Sources for Sewage and Waste-Water Treatment," Proceedings of a Symposium on Radiation for a Clean Environment, IAEA, Munich, March 17-21, 1975.

3. V. R. D. Herrnberger, "Fission Product Gamma-Ray Sources as an Alternative to Cobalt-60 Sources for Sewage Sludge Sterilization, "Proceedings of a Symposium on Radiation for a Clean Environment, IAEA, Munich, March 17-27, 1975.

4. R. W. McKee, Technical, Economic and Policy Considerations Affecting Future Production, Marketing and Use of Cesium-137 and Strontium-90, BNWL-1686, Batte1le-Northwest, Richland, WA, December 1972.

5. R. A. Harrod, "Other Sterilization Processes," Gamma Radiation Processing Seminar, Atomic Energy of Canada Limited, Ottawa, Canada, September 29 October 2, 1975.

6. M. R. Cleland et al., "Use of High-Power Electron Beam Radiation for the Treatment of Municipal and Industrial Wastes," Proceedings from a Symposium on Radiation for a Clean Environment, IAEA, Munich, March 17-21, 1975.

7. A. Brynjolfsson, "Factors Influencing Economic Evaluation of Irradiation Processing," Proceedings of a Panel on Factors Influencing the Economical Application of Food Irradiation, IAEA, Vienna, Austria, June 14-18, 1971.

8. J. Deitch, "Cost Considerations for the Establishment and Operation of a Commercial Food Irradiation Facility," Proceedings of a Symposium on Radiation Preservation of Food, IAEA and FAO, Bombay, India, November 13$17,1972$.

9. M. C. Cleland, "Prospects for Very High Power Electron Accelerators for Processing High Bulk Materials," paper presented at the International Meeting on Radiation Processing sponsored by the American Nuclear Society, American Chemical Society, and Society of Plastic Engineers, May 9-13, 1976, Dorado Beach, Puerto Rico.

10. Buyers Guide Seventy Six, Nuclear News, Voi. 19, No. 3, February 1976.

11. M. R. Fleming, Processing with Cobalt-60, Atomic Energy of Canada Limited, Ottawa, Canada.

12. R. R. Jackson, "Hanford Waste Encapsulation: Strontium and Cesium," paper to be presented to the Materials Science and Technology Division of the American Nuclear Society, Toronto, Canada, June 13-18, 1976, ARH-SA-247, Atlantic Richfield Hanford Co., Richland, WA, May 1976.

13. R. E. Malenfant, QAD: A Series of Point-Kernel General Purpose Shielding Programs, LA-3573, Los A7amos Scientific Laboratory, April 1967. 
14. J. R. LaRiviere, Radioactive Waste Encapsulation and Storage Facility, ARH-SA-115, Atlantic Richfield Hanford Company, JuTy 1972.

15. S. J. Rimshaw and E. E. Ketchen, CS-137 Data Sheets, ORNL-4186, Oak Ridge National Laboratory, December 1967.

10́. Progress Report - Beneficial Uses Program Period Ending December 31, 1976, SAND 76-0065, Sandia Laboratories, Albuquerque, NM, February 1975.

17. H. D. Sivinski, "Animal Feeding of Irradiated Food Sludge," to be presented at the 36th Annual Institute of Food Technologists Meeting, Anaheim, CA, June 6-9, 1976.

18. R. A. Libby, Source Efficiency Calculations for ${ }^{137}$ CS Irradiators, BNWL2064, Battelle-Northwest, Richland, WA, (In Publication), June 1976.

19. H. D. Sivinski, "Treatment of Sewage Sludge with Combinations of Heat and Ionizing Radiation (Thermoradiation)," Proceedings from a Symposium on Radiation for a Clean Environment, IAEA, Munich, March 17-21, 1975.

20. C. M. Heeb, The Availability of Useful Isotopes from Civilian Nuclear Power Reactors to the Year 2000, BNWL-B-435 (Attachment), BattelleNorthwest, Richland, WA, July 1975.

21. P. M. Wood and H. A. Harrel, Potential Market for By-Product Cesium from Commercial Power Reactors, AECOP-754, AEC Combined Operations Planning, Oak Ridge, TN, April 20, 1971.

22. Alternatives for Managing Wastes from Reactors and Post-Fission Operations in the LWR Fuel Cycle, ERDA-76-43, Apri1 1976.

23. H. C. Carney, Ed., Curium-244/Neptunium-237 Recovery from the Barnwel1 Nuclear Fuel Plant, GA-A13348, General Atomic Co., San Diego, CA, February 1975. 


\section{DISTRIBUTION}

NO. OF

COPIES

OFFSITE

1

ERDA Chicago Patent Attorney

9800 S. Cass Avenue

Argonne, IL 60439

A. A. Churm

1

ERDA Division of Biomedical and Environmental Research Washington, DC 20545

J. N. Maddox

2

ERDA Division of Production and Materials Management Washington, DC 20545

F. P. Baranowski

R. W. Ramsey, Jr.

11

ERDA Nuclear Research and Applications Division Washington, DC 20545

R. T. Carpenter

G. P. Dix

T. J. Dobry, Jr.

N. Goldenberg

A. P. Litman (3)

J. J. Lombardo

W. C. Remini

B. J. Rock

E. J. Wahlquist

ERDA Oak Ridge Operations Office

P. 0. Box E

Oak Ridge, TN 37830

D. C. Davis, Jr.

2

ERDA Savannah River Operations Office

T. B. Hindman

R. K. Huntoon

27

ERDA Technica1 Information Center 
Department of the Army

Headquarters, U.S. Army

Facilities Engineering Support Agency

Fort Belvoir, VA 22060

H. Musselman, Technical Director

Electronics and Applied Physics Division

Building 347.3, AERE Harwel1

Oxfordshire 0X11 ORA

Great Britain

E. H. Cooke-Yarborough

General Atomic Company

P. 0. Box 81601

San Diego, CA 92138

H. C. Carney

General Electric Company MSVD

P. 0. Box 8555

Philadelphia, PA 19101

P. E. Brown

L. Tyakla

General Electric Company, Vallecitos Laboratory

P. 0. Box 846

Pleasanton, CA 94566

M. Ebort

Los Alamos Scientific Laboratory

P. 0. Box 1663

Los Alamos, NM 87544

R. N. Mulford

Monsanto Research Corporation

Mound Laboratory (ERDA)

Nuclear Operations

P. 0. Box 32

Miamisburg, OH 45342

$R$. Dewitt

Naval Nuclear Power Unit

P. 0. Box 96

Fort Belvoir, VA 22060

F. E. Rosel1 
NO. OF

COPIES

1

Naval Facilities Engineering Command

Nuclear Power Division (FACO4N)

200 Stovall Street

Alexandria, VA 22332

G. E. Krauter

1

Navy Office of the Chief of Naval Operations

Washington, DC 20390

Head, Reactor Branch

2

Holifield National Laboratory

Dak Ridge, TN 37830

J. R. DiStefano

E. Lamb

2

Sandia Laboratory

A1buquerque, NM 87115

M. Morris

H. D. Sivinski

1

Teledyne Energy Systems

$110 \mathrm{~W}$. Timonium Road

Timonium, MD 21093

R. Hannah

U.S. Army Natick Laboratory Natick, MA 01760

Dr. A. Brynjolfsson

U.S. Department of Commerce

Bureau of Domestic Commerce Room 1001

Washington, DC 20902

J. Deitch

1

Westinghouse Astronuclear Laboratory

P. 0. Box 1086

Pittsburgh, PA 15236

C. C. Silverstein 
NO. OF

COPIES

ONSITE

3

ERDA Richland Operations

W. C. Johnson

P. G. Holsted

W. A. Burns

8

Atlantic Richfield Hanford Company

L. I. Brecke

H. H. Hopkins

R. E. Isaacson

R. E. Jackson

L. M. Knights

C. W. Malody

J. D. Moore

H. P. Shaw

47

Battelle-Northwest

J. W. Bartlett

C. L. Brown

M. 0. Cloninger

T. F. Demmitt

H. T. Fullam

K. M. Harmon

J. H. Jarrett

0. H. Koski

R. A. Libby (5)

R. W. McKee

R. E. Nightingale

D. E. 0lesen

J. A. Partridge

L. D. Perrigo

A. M. Platt

C. A. Rohrman

W. E. Sande (20)

J. L. Simmons

H. H. Van Tuyl

Technical Information Files (3)

Technical Publications (2) 